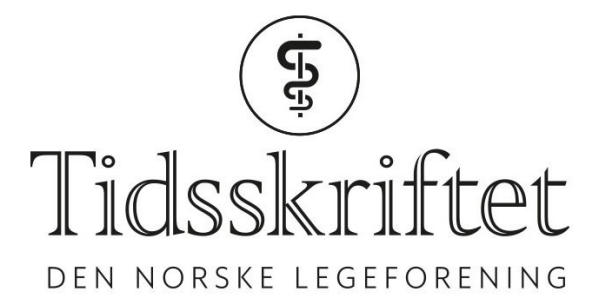

\title{
Nytt koronavirus: Tiden er inne til å ta drastiske grep
}

DEBATT

GUNNAR HASLE

E-post: hasle@reiseklinikken.com Gunnar Hasle er lege ved Reiseklinikken.

Forfatteren har fylt ut ICMJE-skjemaet og oppgir ingen interessekonflikter.

Vi kan stå overfor en svært alvorlig pandemi. Erfaringene fra Kina tyder imidlertid på at SARS-CoV-2-viruset kan stoppes.

Det var rapportert 27 tilfeller av det nye viruset ved årsskiftet. Seks uker senere var det ca. 75 ooo (1). Kina har iverksatt smitteverntiltak som ikke ligner på noe som har vært gjort siden 18oo-tallet, med store omkostninger for befolkningen. Det ser per i dag (26.2.2020) ut til at de har greid å snu trenden. Hvis de ikke hadde satt inn mottiltak, ville en fortsatt eksponentiell vekst vært tenkelig.

Dødeligheten av SARS-CoV var 9,6\%, og antallet symptomfrie infeksjoner var nesten lik null (2). Det foreligger ennå ingen antistofftester som kan gi oss svaret på om et symptomfritt forløp er vanlig ved infeksjoner med SARS-CoV-2, men det synes klart at viruset kan overføres før det gir symptomer hos bærerne (3). En prepublisert studie fra Japan viste at blant 565 japanere som var evakuert fra Kina, var det fem asymptomatiske smittebærere og syv med symptomer (4). Forskere tilknyttet WHO har beregnet at ca. 2/3 av tilfeller eksportert fra Kina kan være uoppdaget (5).

Worldometer gir daglig oppdaterte grafer om utviklingen av koronavirusepidemien (1). Data fra 25. februar 2020 indikerer at $18 \%$ av dem som blir syke, får alvorlig infeksjon. Antallet døde delt på summen av alle som er døde eller er blitt friske, er $8,4 \%$. Antallet døde delt på antallet påviste tilfeller er $3,4 \%$. Men hvis vi ser på antallet døde delt på antallet tilfeller 14 dager tidligere, får vi en dødelighet på 6,1 \%. Disse tallene er dominert av tall fra Kina, og må tolkes med forbehold.

Alle land som har ressurser til det, har nå et ansvar for å hindre utviklingen av en stor pandemi

Vi vet ikke hvor mange av de som blir smittet, som dør. Institute for Disease Modeling anslår 0,94\% (konfidensintervall 0,37-2,95) (6). Foreløpige data indikerer at det nye viruset gir litt lavere dødelighet enn det første SARS-viruset, men det kan være flere symptomfrie smittebærere, noe som kan gjøre det vanskeligere å stoppe. I og med at verdens befolkning ikke har noen immunitet mot dette viruset, må vi regne med at mange kan bli smittet. Det stemmer med observasjoner av familiemedlemmer til smittebærere. 
Folkehelseinstituttet anbefaler ingen karantene ved innreise og legger opp til at smittebærere som ikke er alvorlig syke, kan isoleres hos sin familie hjemme (7).

Det store spørsmålet er om denne epidemien kan stoppes. Tallene fra Kina tyder på det (1)om man går langt nok i å iverksette mottiltak. Gro Harlem Brundtland sa om SARS i april 2003 at det fortsatt fantes muligheter til å stanse spredningen. Og hun fikk rett (8).

Det vil være svært vanskelig å kontrollere epidemien om den skulle etablere seg i et fattig land, for eksempel i Afrika. Alle land som har ressurser til det, har nå et ansvar for å hindre utviklingen av en stor pandemi. Hva kan vi gjøre? Norge er godt forberedt på å ta imot enkelttilfeller, men ingen land er forberedt på en stor pandemi.

Det bør nå etableres karantenefasiliteter, for eksempel i form av brakker med fjernsyn og internett

Det beste er om vi kan hindre spredning før det etableres en epidemi i Norge. Allerede er primærhelsetjenesten godt i gang med forberedelsene til å ta imot mulig smittede, og sykehusene til å ta imot alvorlig syke. Det bør nå etableres karantenefasiliteter, for eksempel i form av brakker med fjernsyn og internett, hvor friske kontakter av smittebærere kan isoleres om de ikke bor alene eller har en hytte de kan bo i i to uker. Det bør opprettes avdelinger der smittede med ingen eller lettere symptomer kan isoleres sammen.

Etter min mening er det ikke grunnlag for å avlyse nært forestående turer til områder hvor det ikke er utbrudd, men det er klokt å ikke bestille unødvendige utenlandsreiser utover våren. Man bør ikke reise til områder med utbrudd av SARS-CoV-2, og hjemkomne fra slike områder bør settes i karantene i to uker.

\section{LITTERATUR:}

1. Worldometer. Coronavirus Update (Live). https://www.worldometers.info/coronavirus/ Lest 26.2.2020.

2. Leung GM, Chung PH, Tsang T et al. SARS-CoV antibody prevalence in all Hong Kong patient contacts. Emerg Infect Dis 2004; 10:1653-6. [PubMed][CrossRef]

3. Chan JFW, Yuan S, Kok KH et al. A familial cluster of pneumonia associated with the 2019 novel coronavirus indicating person-to-person transmission: a study of a family cluster. Lancet 2020;395: 514-23. [PubMed][CrossRef]

4. Nishiura H, Kobayashi T, Miyama T et al. Estimation of the asymptomatic ratio of novel coronavirus infections (COVID-19). medRxiv 2020; 2020.02.03.20020248.

5. Bhatia S, Imai N, Cuomo-Dannenburg G et al. Report 6: Relative sensitivity of international surveillance. WHO Collaborating Centre for Infectious Disease Modelling, MRC Centre for Global Infectious Disease Analysis, Abdul Latif Jameel Institute for Disease and Emergency Analytics (J-IDEA), Imperial College London, 2020: 6.

https://www.imperial.ac.uk/media/imperial-college/medicine/sph/ide/gida-fellowships/Imperial-Coll ege-COVID-19-Relative-Sensitivity-International-Cases.pdf Lest 26.2.2020.

6. Famulare M. 2019-nCoV: preliminary estimates of the confirmed-case-fatality-ratio and infectionfatality-ratio, and initial pandemic risk assessment.

https://institutefordiseasemodeling.github.io/nCoV-public/analyses/first_adjusted_mortality_estima tes_and_risk_assessment/2019-nCoV-

preliminary_age_and_time_adjusted_mortality_rates_and_pandemic_risk_assessment.html Lest 26.2.2020.

7. Folkehelseinstituttet. Nytt koronavirus (coronavirus) - fakta, råd og tiltak.

https://fhi.no/nettpub/coronavirus/ Lest 26.2.2020.

8. Bleness C. Brundtland: SARS kan stoppes. Aftenposten 27.4.2003.

https://www.aftenposten.no/norge/i/63Mwe/brundtland-sars-kan-stoppes Lest 26.2.2020. 
Publisert: 27. februar 2020. Tidsskr Nor Legeforen. DOI: 10.4045/tidsskr.20.0162 (C) Tidsskrift for Den norske legeforening 2020. Lastet ned fra tidsskriftet.no 